\title{
Review of eating disorders and oxytocin receptor polymorphisms
}

Victoria Burmester $^{1^{*}}$ (D), Dasha Nicholls', Alexis Buckle ${ }^{1}$, Boban Stanojevic ${ }^{2,3}$ and Marta Crous-Bou ${ }^{4,5}$

\begin{abstract}
Background and aims: Oxytocin, a nine amino acid peptide synthesised in the hypothalamus, has been widely recognised for its role in anxiolysis, bonding, sociality, and appetite. It binds to the oxytocin receptor (OXTR) — a Gprotein coupled receptor-that is stimulated by the actions of oestrogen both peripherally and centrally. Studies have implicated OXTR genotypes in conferring either a risk or protective effect in autism, schizophrenia, and eating disorders (ED). There are numerous DNA variations of this receptor, with the most common DNA variation being in the form of the single nucleotide polymorphisms (SNPS). Two OXTR SNPs have been most studied in relation to ED: rs53576 and rs2254298. Each SNP has the same allelic variant that produces genotypes AA, AG, and GG. In this critical review we will evaluate the putative role of rs53576 and rs2254298 SNPs in ED. Additionally, this narrative review will consider the role of gene-environment interactions in the development of ED pathology.

Findings: The OXTR SNPs rs53576 and rs2254298 show independent associations between the A allele and restrictive eating behaviours. Conversely, the G allele of the OXTR rs53576 SNP is associated with binging behaviours, findings that were also evident in neuroanatomy. One study found the A allele of both OXTR SNPs to confer risk for more severe ED symptomatology while the $\mathrm{G}$ allele conferred some protective effect. An interaction between poor maternal care and rs2254298 AG/AA genotype conferred increased risk for binge eating and purging in women.

Conclusions: Individual OXTR SNP are unlikely in themselves to explain complex eating disorders but may affect the expression of and/or effectiveness of the OXTR. A growing body of $\mathrm{G} \times \mathrm{E}$ work is indicating that rs53576G homozygosity becomes disadvantageous for later mental health under early adverse conditions but further research to extend these findings to eating pathology is needed. The GWAS approach would benefit this area of knowledge.
\end{abstract}

\footnotetext{
* Correspondence: v.burmester@imperial.ac.uk

'Department of Brain Sciences, Division of Psychiatry, Imperial College London, Burlington Danes, The Hammersmith Hospital, Du Cane Road, London W12 ONN, UK

Full list of author information is available at the end of the article
}

(c) The Author(s). 2021 Open Access This article is licensed under a Creative Commons Attribution 4.0 International License, which permits use, sharing, adaptation, distribution and reproduction in any medium or format, as long as you give appropriate credit to the original author(s) and the source, provide a link to the Creative Commons licence, and indicate if changes were made. The images or other third party material in this article are included in the article's Creative Commons licence, unless indicated otherwise in a credit line to the material. If material is not included in the article's Creative Commons licence and your intended use is not permitted by statutory regulation or exceeds the permitted use, you will need to obtain permission directly from the copyright holder. To view a copy of this licence, visit http://creativecommons.org/licenses/by/4.0/. The Creative Commons Public Domain Dedication waiver (http://creativecommons.org/publicdomain/zero/1.0/) applies to the data made available in this article, unless otherwise stated in a credit line to the data. 


\section{Plain English summary}

Oxytocin is a chemical made in the brain that affects human behaviour in areas from anxiety, bonding right through to appetite. Oxytocin works by binding to a specific cellular receptor. In humans, the genes that specify this receptor are found in slightly different versions that are inherited from each parent. Research has suggested that individuals who possess speicfic combinations of oxytocin receptor gene variants may be more susceptible to certain kinds of mental illness. This paper considers two different versions of the oxytocin receptor gene most studied in relation to eating disorders. The two different versions considered in this review do not seem to affect the structure of the oxytocin receptor itself. Together, research indicates that the presence or absence of a particular receptor gene variant in an individual might have some predictive capability in respect of potential susceptibility to eating disorders. However, further research is necessary as some of the findings are contradictory. In addition, environmental factors — such as poor maternal care early in life-have also been demonstrated to be important in determining whether an individual will develop an eating disorder. Research in this area would benefit from non-hypothesis driven studies.

\section{Background}

\section{Overview of oxytocin}

The nine-amino acid peptide oxytocin is synthesised mainly in the hypothalamus and secreted directly within the cerebrum but also released via the posterior pituitary gland to regulate a range of physiologic and metabolic processes [1]. Centrally, oxytocin has a wide distribution and is recognised for its context-dependent behavioural effects in mammals including anxiolysis, bonding, appetite, and sociality [2].

Oxytocin is an anorectic with multifarious hypophagic controls, including homeostatic satiety-related signalling between the peripheral and central nervous system, metabolic modulation, supraoptic nuclei metabolic feedback, and the reduction of feeding reward [3]. Blockade of OXTR in mice results in hyperphagia [4]. Exogenous oxytocin is an effective anorexiant in animals, both via systemic administration [5-7] and intracerebroventricular (ICV) routes [8], which is reversed by antagonists [911]. In men [12] and women [13], intranasal oxytocin inhibits postprandial snack intake.

The anorectic effects of chronic oxytocin administration have not been widely studied. However, repeated ICV injections of oxytocin agonist (e-L- $\left.\beta-M e P h e^{2}\right) \mathrm{OT}$, inhibited feeding in rats but also produced tolerance [14]. In diet-induced obese rhesus monkeys, chronic oxytocin across a four-week period effectively reduced body mass [15]. However, chronic oxytocin in mice facilitated observational fear and downregulated oxytocin receptors in the amygdala without tolerance or reductions in body mass, suggesting that oxytocin does not cause organisms to lose weight beyond their limits [16]. In obese humans, chronic oxytocin over an eight-week period reversed obesity and prediabetic changes [17].

Studies in people with Prader Willi Syndrome who have decreased oxytocin-producing neurons [18] and decreased functional OXTR [19], together with studies in animals, have underlined the importance of oxytocin and genetics in determining appetite and body mass. For example, in Prader-Willi, both the size of the oxytocincontaining paraventricular nucleus $(\mathrm{PVN})$ and the number of oxytocin neurons within it, are dramatically reduced, which is thought to cause the dramatic hyperphagia seen with the syndrome [18]. Similarly, mice with haploinsufficiency of the single-minded 1 gene that influences PVN maturation, develop extreme hyperphagia and are susceptible to diet-induced obesity [4]. In the PVN, expression of the synaptotagmin gene results in synaptotagmin-4, a protein that negatively regulates oxytocin release via exocytosis. Increased vesicle binding of synaptotagmin-4 in oxytocin neurons is associated with obesity and mice overexpressing synaptotagmin- 4 are obesogenic in contrast to mice deficient in synaptotagmin-4 that are resistant to diet-induced obesity [20].

Oxytocin concentrations have been studied in relation to eating disorders. Low-weight women with anorexia nervosa (AN) have lower serum oxytocin concentrations than healthy controls, and postprandial oxytocin concentrations were associated with ED psychopathology [21]. Additionally, functional magnetic resonance imaging ( $\mathrm{AMRI}$ ) hypoactivation of relevant neural reward and homeostatic circuitry was seen in $\mathrm{AN}$ and weight-recovered $\mathrm{AN}$, that was associated with plasma concentration oxytocin and disordered eating psychopathology [22, 23].

\section{OXTR overview}

There is evidence to support that sensitivity to oxytocin, which is thought to be mediated by genetic and epigenetic alterations in the OXTR gene, might play a role in criterion eating disorder behaviours [24]. The OXTR itself is a G-protein coupled receptor (GPCR) expressed widely in the mammalian brain. The distribution pattern of OXTR is species-specific and indicates the level of sociability for a species. In solitary species, such as the 
montane vole, the expression of OXTR increases dramatically during the mating season to facilitate breeding activities-including mate bonding and maternal care-behaviours blocked by OXTR antagonists [25, 26]. The striking cell-specific up- and downregulation of OXTRs is atypical of the GPCR superfamily and also occurs in females during parturition. The OXTR is stimulated by oestrogen both peripherally and in central hypothalamic sites with behavioural actions [27-29]; however, the degree to which the OXTR is oestrogen sensitive remains unclear [30]. Nonetheless, there are gender differences in oxytocin function and OXTR expression [31-41].

In humans, the OXTR is located on chromosome $3 \mathrm{p} 25$, spanning $17 \mathrm{~kb}$, and containing three introns and four exons [31, 42]. The identified variations of the OXTR are SNPs-the most common form of DNA variation-and occur when one nucleotide of a base pair is replaced by another nucleotide. The two most studied OXTR SNPs in relation to ED are rs53576 and rs2254298, (see Table 1 for their genotypic distributions across ethnicities), with two possible allelic variants, guanine (G) and adenosine (A). An individual may inherit either the $G$ or the $A$ allele for each one of the SNPs of the OXTR from each parent and, thus, an individual would be homozygous if inheriting the same allele from both parents (AA or GG) or heterozygous if different alleles are inherited derived from each parent (AG). There are, therefore, three genotypes for each of these SNP: GG, AG, and AA. Since rs53576 and rs2254298 are located in the non-coding third intron of the OXTR, there is no effect in the expression of the OXTR protein.

\section{OXTR gene in mental Health Research}

Variations in the OXTR gene were first linked to human mental health, specifically in autism research, that extended the work demonstrating the links between the

Table 1 Summary of Genotypic Distributions for OXTR rs53576 and rs 2254298

\begin{tabular}{|c|c|c|c|c|c|c|c|}
\hline & & \multicolumn{6}{|c|}{ Frequencies } \\
\hline & & \multicolumn{3}{|l|}{ Allele } & \multicolumn{3}{|c|}{ Genotype } \\
\hline \multicolumn{8}{|l|}{ rs53576 } \\
\hline Population & Number & A & G & Number & $\mathrm{AA}$ & $A G$ & GG \\
\hline African & 1194 & 0.224 & 0.776 & 597 & 0.057 & 0.33 & 0.610 \\
\hline American & 524 & 0.343 & 0.657 & 262 & 0,116 & 0.453 & 0.431 \\
\hline Asian & 1144 & 0.684 & 0.316 & 662 & 0.472 & 0.423 & 0.105 \\
\hline European & 1990 & 0.361 & 0.639 & 995 & 0.132 & 0.459 & 0.409 \\
\hline \multicolumn{8}{|l|}{ rs2254298 } \\
\hline African & 1112 & 0.238 & 0.762 & 561 & 0.053 & 0.370 & 0.577 \\
\hline American & 524 & 0.240 & 0.760 & 262 & 0.083 & 0.315 & 0.602 \\
\hline Asian & 968 & 0.322 & 0.678 & 484 & 0.101 & 0.441 & 0458 \\
\hline European & 2318 & 0.107 & 0.893 & 1159 & 0.016 & 0.182 & 0.802 \\
\hline
\end{tabular}

$O X T R$ and sociability in voles. The hypothesis that variation in the OXTR was associated with deficits in social behaviour was substantiated by a study linking rs53576 and rs2254298 to autism [43]. Despite inconsistent findings from subsequent autism and OXTR studies, research into the broader hypothesis that OXTR polymorphisms are associated with social dysfunction has increased and has been extended to explain other psychopathology, such as depression, schizophrenia and ED, as well as general social functioning [44-47].

\section{Genetic risk factor identification strategies}

Broadly, there are two approaches for identifying genetic risk factors associated to a specific phenotype. The first is the candidate-gene approach, which investigates prespecified gene variations in relation to a specific phenotype. This hypothesis-driven approach differs from datadriven genome-wide association studies (GWAS) and quantitative trait locus mapping that analyse the DNA sequence of the entire genome to identify genetic risk factors for phenotypes, usually diseases that are common in the population. Research into the OXTR and ED has so far pursued only the candidate-gene approach. In addition to common genetic variation, rare gene mutation may identify critical mechanisms in pathology.

In addition to genetic variation, changes in the activity of OXTR may be related to other non-genetic regulatory mechanisms of transcription, such as DNA methylation-an epigenetic mechanism involving the transfer of a methyl group onto the C5 position of the cytosine to form 5-methylcytosine. Epigenomic changes might alter DNA accessibility thereby regulating patterns of gene expression [48]. Consistent with an emerging field of inquiry, functional studies have shown that differential methylation of a CpG island in the OXTR promoter have been reported in relation to disorders characterized by impairments in social cognition, including Autistic Spectrum Disorder, eating behaviour, such as anorexia nervosa, and problems with facial and emotional recognition [49-52]. However, taken together, these findings are in pressing need of greater phenotypic precision and methodological improvements including longitudinal studies with multiple time-points, validation in larger and more homogeneous samples, and measures of DNA methylation status of other genes within the same functional circuitry, such as the oxytocin transporter gene, CD38 [53].

\section{Aims and objectives}

The aim of this critical review is to explore research into OXTR rs53576 and rs2254298 SNPs and their role in clinical and non-clinical samples with, or displaying behaviours characteristic of, $\mathrm{AN}, \mathrm{BN}$ or binge-eating disorder. 


\section{Methods}

\section{Inclusion and exclusion criteria}

Research was included in this review if it was written in English, peer-reviewed and explored rs53576 or rs2254298 and ED behaviours together (see Table 2 for a summary of papers included and their main findings). Both clinical and nonclinical populations were included, and no date restrictions were imposed. Research exploring other OXTR SNPs, the oxytocin gene itself, oxytocin secretion, and oxytocin administration were excluded from this review. Studies examining the OXTR gene and parturition have also been excluded, given the upregulation of oxytocin in the third trimester. Research that relies on salivary or plasma oxytocin concentrations has also been omitted as the validity of these measurements is not decided.

\section{Search strategy}

Papers for inclusion were identified by searching the Single Nucleotide Polymorphism Database (dbSNP) of Nucleotide Sequence Variation [60] for studies using the rs53576 [Homo sapiens] and rs2254298 [Homo sapiens] classification, which returned 184 and 109 publications, respectively. These publications were searched for studies that mentioned eating behaviour or eating disorders, leaving only six studies. The GWAS Catalog [61] was also searched for rs53576 and rs2254298, and neither SNP was found. In addition, PubMed and Google Scholar were searched for peer-reviewed articles using the terms rs53576 OR rs2254298 OR oxytocin receptor
OR OXTR, AND eating disorder OR anorexia nervosa OR bulimia nervosa OR binge/binging, but no additional papers were found.

\section{OTXR polymorphisms and eating disorders}

Only six studies have addressed the association between OXTR SNPs and ED behaviours: two in clinical cohorts and two using ED pathology in the general population. Despite this paucity of research, the emerging results are broadly consistent.

A large-scale hypothesis-free investigation of pregnant women from the Avon Longitudinal Study of Parents and Children (ALSPAC) cohort found that participants with the OXTR GG genotype in the rs53576 were more likely to have self-induced vomiting or used laxatives for weight loss [54]. However, results should be taken with caution as these were the only significant findings among 22 analyses conducted on the data and, therefore, may be due to chance alone.

In a community sample comprised of 3698 women recruited as part of the ALSPAC, Micali et al. investigated the relationship between the OXTR SNPs rs53576 and rs2254298, maternal care and eating behaviours [55]. The study concluded that regarding rs53576 variant, the A allele negatively correlated with binging or purging behaviours and that, conversely, women who were $G$ homozygotes had increased odds of binging or purging behaviours $(p=.01)$ The SNP rs2254298 was most strongly associated with restrictive eating behaviour, in particular the A allele, with A-allele carriers and homozygotes

Table 2 Population Characteristics and Key Findings in Studies of OXTR rs53576 or rs2254298 and ED behaviour

\begin{tabular}{|c|c|c|c|c|}
\hline $\begin{array}{l}\text { Review } \\
\text { Subsection }\end{array}$ & Authors & Sample & Summary of Study Findings - rs53576 & Summary of Study Findings - rs225498 \\
\hline \multirow[t]{5}{*}{$\begin{array}{l}\text { OXTR Variants } \\
\text { and ED }\end{array}$} & $\begin{array}{l}\text { Connelly } \\
\text { et al. [54] }\end{array}$ & $\begin{array}{l}\text { Community } \\
\text { sample of } \\
\text { females }\end{array}$ & $\begin{array}{l}\text { GG genotype more likely to have engaged in vomiting } \\
\text { or laxative use as weight loss strategy }\end{array}$ & \\
\hline & $\begin{array}{l}\text { Micali } \\
\text { et al. [55] }\end{array}$ & $\begin{array}{l}\text { Community } \\
\text { sample of } \\
\text { females }\end{array}$ & $\begin{array}{l}\text { A allele negatively correlated to binging/purging } \\
\text { behaviours, GG genotype was at increased risk of } \\
\text { engaging in binging and purging }\end{array}$ & $\begin{array}{l}\text { A allele carriers at increased odds of } \\
\text { restrictive eating/purging } \\
\text { A allele carriers who had experienced poor } \\
\text { maternal care at increased odds of binging } \\
\text { purging }\end{array}$ \\
\hline & $\begin{array}{l}\text { Kim et al. } \\
{[56]}\end{array}$ & $\begin{array}{l}\text { Females (age } \\
\text { range not } \\
\text { specified) } \\
\text { with AN, BN and } \\
\text { HC }\end{array}$ & $\begin{array}{l}\text { G allele positively associated with BN, stronger } \\
\text { association observed in those with } \mathrm{AG} \text { genotype }\end{array}$ & \\
\hline & $\begin{array}{l}\text { Acevedo } \\
\text { et al. [57] }\end{array}$ & $\begin{array}{l}\text { Adult females } \\
\text { with AN, BN and } \\
\text { HC }\end{array}$ & \multicolumn{2}{|c|}{$\begin{array}{l}\text { Positive association between A allele carriers of either/both SNPs and severity of ED symptomatology } \\
\text { In those with previous AN, A allele carrier status increased severity of cognitions and eating } \\
\text { behaviours }\end{array}$} \\
\hline & $\begin{array}{l}\text { Davis } \\
\text { et al. [58] }\end{array}$ & $\begin{array}{l}\text { Community } \\
\text { sample of adults }\end{array}$ & \multicolumn{2}{|l|}{ No significant effects for either SNP } \\
\hline $\begin{array}{l}\text { OXTR and } \\
\text { Brain } \\
\text { Structure/ } \\
\text { Function }\end{array}$ & $\begin{array}{l}\text { Sala et al. } \\
{[59]}\end{array}$ & $\begin{array}{l}\text { Adult females } \\
\text { with, or } \\
\text { recovered from, } \\
\text { AN }\end{array}$ & & $\begin{array}{l}\text { Reduced activation of brain areas } \\
\text { underpinning social salience and reflection } \\
\text { observed in A allele carriers } \\
\text { Greater negative connectivity observed in A } \\
\text { allele carriers }\end{array}$ \\
\hline
\end{tabular}


having increased odds of engaging in restrictive eating and purging behaviours $(p<.0001$ and $p=.03$, respectively). Poor maternal care was independently positively associated with binging and purging but only interacted significantly with the rs2254298 A allele, carriers of which were four times more likely to engage in binging/ purging $(p=.03)$. The study's strengths lie in its large sample size and longitudinal design, which allowed for evaluation of eating behaviours over time; however, the authors recognise that given the low frequency of certain eating behaviours, the sample may not have been sufficiently powered to identify small associations.

In a clinical sample of 90 women with bulimia nervosa (BN) examining six OXTR SNPs, which included rs53576 and rs2254298, the G allele of rs53576 was positively correlated with $\mathrm{BN}$ [56]. However, the authors acknowledge that results were not corrected for multiple testing and, had the alpha level been lowered, the significant association between genotype and $\mathrm{BN}$ would have disappeared. In addition, the heterozygous genotype (AG) was more strongly associated with $\mathrm{BN}$ than the homozygous (GG), creating interpretative difficulties in asserting that the $G$ allele confers risk for BN. No further associations were found among genotype distributions or allele frequencies for the other OXTR gene SNPs and AN or BN.

A study investigating the link between ED symptomatology and five OXTR SNPs in a sample of 124 females with and without ED found a positive correlation between rs53576 and rs2254298 in the A-allele carriers and the severity of ED symptomatology [57]. Moreover, for individuals with a previous history of $\mathrm{AN}$, carrying at least one copy of the A allele for both the rs53576 and rs2254298 SNPs, was associated with increased ED symptom severity in relation to both cognition and eating behaviours. This finding also suggests that rs53576rs2254298 GG/GG haplotypes may confer some protective effect as evidenced by lower reported anxiety and preoccupation with body and food in both healthy controls and those with a previous history of AN and in weight recovery.

A further exploratory study in a community sample of 460 adults examined the association between overeating and seven OXTR SNPs, including rs53576 and rs2254298, reported no significant effects with respect to either SNP [58]. However, linkage disequilibrium analysis revealed that within a four SNP haplotype, the GT-A-G haplotype formed of the rs237885, rs2268493, rs2268494 and rs2254298 respectively, was associated with higher food preference scores. Food preference scores were a measure of preference of high fat and/or sugar foods-those characteristic of a binge-thus it may be inferred that the $G$ allele of rs225498 somewhat contributes to the risk of binging behaviours.

\section{OXTR polymorphisms and brain structure/function}

Only one brain imaging study has so far examined the OXTR rs53576 or rs2254298 and ED (see Table 2). Using $f$ MRI, Sala et al. evaluated neural responses to a social attribution task in adult women with, or recovered from, AN [60]. In line with the finding that rs2254298 AG or AA genotypes were associated with restrictive eating behaviours [55], females with AN had reduced activation of brain areas subserving social salience and reflection during a social attribution task [59]. Specifically, reduced activation of principal components of the default mode network (medial prefrontal cortex, posterior cingulate cortex, and precuneus) that underpin introspective decision-making and thinking about self or others was seen in rs2254298 A carriers relative to rs2254298 G homozygotes. In addition, negative connectivity among the posterior cingulate cortex, the occipital lobe and the cerebellum was greater in rs2254298 A heterozygotes than in rs2254298 GG homozygotes, meaning activation patterns in areas associated with bottom-up attention, vision and voluntary body movement were negatively correlated. However, data from this study may not be reliable due to its small sample size and unequal group numbers.

\section{Gene-environment interactions in ED}

If an increased risk for a phenotype is conferred by an environmental factor, then a gene by environment ( $\mathrm{G} x$ E) interaction applies. Only Micali et al. in their abovementioned study also addressed $\mathrm{G} \times \mathrm{E}$ interactions in relation to a disordered eating phenotype [55]. They found that, although the rs2254298 AA or AG genotypes were associated with restrictive eating behaviour, when poor maternal care was present, rs2254298 AA or AG genotypes had a four-fold increase in the odds of binge eating and purging $(p=.03)$ [55].

A number of environmental factors that relate indirectly to ED or allied phenotypes, such as obesity, have also been explored via $\mathrm{G} \times \mathrm{E}$ studies of the OXTR rs53576 and rs2254298 SNPs. A longitudinal study of 192 children examined OXTR rs53576 and its interaction with socioeconomic status to predict the risk of childhood obesity [61]. Authors found that the A allele of rs53567 predicted body mass when socioeconomic status was accounted for [62]. This finding reinforces oxytocin's role in factors that might drive childhood obesity such as metabolic regulation, appetite, and reward-driven eating processes and underlines the importance of studying genetic predispositions to health outcomes. Promising interactions between childhood adversity and rs53576 on later development of psychopathology have been described in three separate G x E studies [63-65]. Although these interactions were not replicated in a later study [66], the neurostructural and 
functional underpinnings of this OXTR rs53576 × childhood adversity interaction have been investigated using $f M R I$ and found to map to the ventral striatum in the reward area of the brain [67]. In GG homozygotes, ventral striatum grey matter volume negatively correlated with the degree of childhood maltreatment, but this detrimental outcome was not seen in A-allele carriers [56]. Interestingly, a review discussing early-life caregiver deprivation and the later development of depression proposed a role for the ventral striatum [68]. Given the role of oxytocin in childhood bonding [24,69-81], these findings are, perhaps, unsurprising. However, attachment and early years' experiences are also established risk factors for the development of ED [82-86], so further research to investigate the impact of the interaction of OXTR polymorphisms and childhood environment on eating behaviours would be useful.

\section{Limitations}

There are a number of difficulties regarding reliability, interpretation, and validity of candidate-gene association studies. Results are often not replicated, and it is not known how often failure to replicate has resulted in failure to publish. In addition, small sample sizes in both original and replication studies create problems of lack of power highlighted as particular problem for both candidate-gene research and neuroscience [87].

There are specific issues pertaining to candidate-gene research using OXTR SNPs. Few studies compare data between women and men, despite evidence of sexspecific effects [88-91] and few studies account for ethnicity, although the minor allele for rs53576 is different in Caucasian and Asian groups. In addition, the same outcomes are rarely measured, making the comparison of results difficult.

\section{Conclusion}

Understanding an aetiologic role for oxytocin in the development of ED is important, not only for researchers, but also for clinicians and patients, with potential new treatment avenues becoming an option for the latter group. However, despite the association of rs53576 and rs2254298 with eating patterns in a non-clinical population study, so far, these SNPs have not been identified in genome-wide association studies examining eating behaviours or obesity. Individual OXTR SNPs are unlikely in themselves to explain complex eating disorders but may form part of a haplotype with other OXTR SNPs to affect the expression of and/or effectiveness of the OXTR. A growing body of $\mathrm{G} \times \mathrm{E}$ work is indicating that rs53576G homozygosity becomes disadvantageous for later mental health under early adverse conditions but further research to extend these findings to eating pathology is needed. Eating disorders are not genetic monoliths but complex behaviours arising from multigenetic-environment interactions over time and the GWAS approach would benefit this area of knowledge.

\section{Abbreviations \\ ED: Eating disorders; $\mathrm{AMRI}$ : Functional magnetic resonance imaging; ICV: Intracerebroventricular; OXTR: Oxytocin receptor; OXTR: Oxytocin receptor gene; PVN: Paraventricular nucleus; SNP: Single nucleotide polymorphism}

\section{Acknowledgements \\ None.}

Authors' contributions

VB conceived the review and wrote the first draft. All authors revised and contributed to manuscript writing. The author(s) read and approved the final manuscript.

Funding

None.

Availability of data and materials Not applicable.

\section{Declarations}

Ethics approval and consent to participate Not applicable.

Consent for publication

Not applicable.

\section{Competing interests}

The authors declare that they have no competing interests.

\section{Author details}

${ }^{1}$ Department of Brain Sciences, Division of Psychiatry, Imperial College London, Burlington Danes, The Hammersmith Hospital, Du Cane Road, London W12 ONN, UK. ${ }^{2}$ Comprehensive Cancer Centre, Faculty of Life Sciences \& Medicine, King's College London, Rayne Institute, 111 Coldharbour Ln, London SE5 9RR, UK. ${ }^{3}$ Laboratory for Radiobiology and Molecular Genetics, "Vinca" Institute of Nuclear Sciences, University of Belgrade, Belgrade, Serbia. ${ }^{4}$ Unit of Nutrition and Cancer, Cancer Epidemiology Research Program, Catalan Institute of Oncology (ICO) Bellvitge Biomedical Research Institute (IDIBELL). L'Hospitalet de Llobregat, Barcelona, Spain. ${ }^{5}$ Department of Epidemiology, Harvard T.H. Chan School of Public Health, Boston, MA, USA.

Received: 29 March 2021 Accepted: 25 June 2021

Published online: 13 July 2021

\section{References}

1. Jones C, Barrera I, Brothers S, Ring R, Wahlestedt C. Oxytocin and social functioning. Dialogues Clin Neurosci. 2017;19(2):193-201.

2. Argiolas A, Gessa GL. Central functions of oxytocin. Neurosci Biobehav Rev. 1991;15(2):217-31. https://doi.org/10.1016/S0149-7634(05)80002-8.

3. Olszewski PK, Klockars A, Schiöth HB, Levine AS. Oxytocin as feeding inhibitor: maintaining homeostasis in consummatory behavior. Pharmacol Biochem Behav. 2010;97(1):47-54. https://doi.org/10.1016/j.pbb.2010.05.026.

4. Kublaoui BM, Gemelli T, Tolson KP, Wang Y, Zinn AR. Oxytocin deficiency mediates hyperphagic obesity of Sim1 haploinsufficient mice. Mol Endocrinol. 2008;22(7):1723-34. https://doi.org/10.1210/me.2008-0067.

5. Arletti $R$, Benelli A, Bertolini A. Oxytocin inhibits food and fluid intake in rats. Physiol Behav. 1990;48(6):825-30. https://doi.org/10.1016/0031-9384 (90)90234-U.

6. Benelli A, Poggioli R, Luppi P, Ruini L, Bertolini A, Arletti R. Oxytocin enhances, and oxytocin antagonism decreases, sexual receptivity in intact female rats. Neuropeptides. 1994;27(4):245-50. https://doi.org/10.1016/ 0143-4179(94)90005-1. 
7. Benelli A, Bertolini A, Arletti R. Oxytocin-induced inhibition of feeding and drinking: no sexual dimorphism in rats. Neuropeptides. 1991;20(1):57-62. https://doi.org/10.1016/0143-4179(91)90040-P.

8. Olson BR, Drutarosky MD, Stricker EM, Verbalis JG. Brain oxytocin receptor antagonism blunts the effects of Anorexigenic treatments in rats: evidence for central oxytocin inhibition of food intake. Endocrinology. 1991;129(2): 785-91. https://doi.org/10.1210/endo-129-2-785.

9. Arletti $\mathrm{R}$, Benelli $\mathrm{A}$, Bertolini A. Influence of oxytocin on feeding behavior in the rat. Peptides. 1989;10(1):89-93. https://doi.org/10.1016/0196-9781 (89) $90082-X$.

10. Maejima Y, Iwasaki Y, Yamahara Y, Kodaira M, Sedbazar U, Yada T. Peripheral oxytocin treatment ameliorates obesity by reducing food intake and visceral fat mass. Aging. 2011;3(12):1169-77. https://doi.org/10.18632/aging.100408.

11. Zhang G, Cai D. Circadian intervention of obesity development via restingstage feeding manipulation or oxytocin treatment. Am J Physiol Endocrinol Metab. 2011;301(5):1004

12. Burmester $V$, Higgs $S$, Terry $P$. Rapid-onset anorectic effects of intranasal oxytocin in young men. Appetite. 2018;130:104-9.

13. Burmester V, Gibson EL, Butler G, Bailey A, Terry P. Oxytocin reduces post-stress sweet snack intake in women without attenuating salivary cortisol. Physiol Behav. 2019;212:112704. https://doi.org/10.1016/j.physbeh.2019.112704.

14. Olson BR, Drutarosky MD, Chow M, Hruby VJ, Stricker EM, Verbalis JG. Oxytocin and an oxytocin agonist administered centrally decrease food intake in rats. Peptides. 1991;12(1):113-8. https://doi.org/10.1016/0196-9781 (91)90176-P.

15. Blevins JE, Graham JL, Morton GJ, Bales KL, Schwartz MW, Baskin DG, Havel PJ. Chronic oxytocin administration inhibits food intake, increases energy expenditure, and produces weight loss in fructose-fed obese rhesus monkeys. Am J Physiol-Regul, Integ Comp Physiol. 2015;308(5):R431-R438.

16. Pisansky MT, Hanson LR, Gottesman II, Gewirtz JC. Oxytocin enhances observational fear in mice. Nat Commun. 2017;8(1):2102. https://doi.org/10.1 038/s41467-017-02279-5.

17. Zhang H, Wu C, Chen Q, Chen X, Xu Z, Wu J, et al. Treatment of obesity and diabetes using oxytocin or analogs in patients and mouse models. Plos One. 2013;8(5):e61477. https://doi.org/10.1371/journal.pone.0061477.

18. Swaab D, Purba JS, Hofman MA. Alterations in the hypothalamic paraventricular nucleus and its oxytocin neurons (putative satiety cells) in Prader-Willi syndrome: a study of five cases. J Clin Endocrinol Metab. 1995; 80(2):573-9.

19. Bittel DC, Kibiryeva N, Sell SM, Strong TV, Butler MG. Whole genome microarray analysis of gene expression in Prader-Willi syndrome. Am J Med Genet Part A. 2007;(5):143A, 430-42. https://doi.org/10.1002/ajmg.a.31606.

20. Zhang G, Bai H, Zhang H, Dean C, Wu Q, Li J, et al. Neuropeptide exocytosis involving synaptotagmin-4 and oxytocin in hypothalamic programming of body weight and energy balance. Neuron. 2011;69(3):523-35. https://doi. org/10.1016/j.neuron.2010.12.036.

21. Afinogenova $Y$, Schmelkin C, Plessow F, Thomas JJ, Pulumo R, Micali N, et al. Low fasting oxytocin levels are associated with psychopathology in anorexia nervosa in partial recovery. J Clin Psychiatry. 2016;77(11):e1483-90. https://doi.org/10.4088/JCP.15m10217.

22. Lawson EA, Holsen LM, Santin M, Meenaghan E, Eddy KT, Becker AE, et al. Oxytocin secretion is associated with severity of disordered eating psychopathology and insular cortex hypoactivation in anorexia nervosa. J Clin Endocrinol Metab. 2012;97(10):E1898-908. https://doi.org/10.1210/jc.2012-1702.

23. Lawson EA, Donoho DA, Blum Jl, Meenaghan EM, Misra M, Herzog DB, et al. Decreased nocturnal oxytocin levels in anorexia nervosa are associated with low bone mineral density and fat mass. J Clin Psychiatry. 2011;72(11):154651. https://doi.org/10.4088/JCP.10m06617.

24. Cataldo I, Azhari A, Lepri B, Esposito G. Oxytocin receptors (OXTR) and early parental care: An interaction that modulates psychiatric disorders. Res Dev Disabilities. 2018;82:27-38.

25. Insel TR, Shapiro LE. Oxytocin receptor distribution reflects social organization in monogamous and polygamous voles. Proc Natl Acad Sci U S A. 1992:89(13):5981-5. https://doi.org/10.1073/pnas.89.13.5981.

26. Champagne F, Diorio J, Sharma S, Meaney MJ. Naturally occurring variations in maternal behavior in the rat are associated with differences in estrogeninducible central oxytocin receptors. Proc Natl Acad Sci. 2001;98(22):1273641. https://doi.org/10.1073/pnas.221224598.

27. Breton C, Zingg HH. Expression and region-specific regulation of the oxytocin receptor gene in rat brain. Endocrinology. 1997;138(5):1857-62 https://doi.org/10.1210/endo.138.5.5127.
28. Vasudevan N, Davidkova G, Zhu Y, Koibuchi N, Chin WW, Pfaff D. Differential interaction of estrogen receptor and thyroid hormone receptor isoforms on the rat oxytocin receptor promoter leads to differences in transcriptional regulation. Neuroendocrinology. 2001;74(5):309-24. https://doi.org/10.1159/ 000054698 .

29. Ostrowski NL. Young 3rd WS, Lolait SJ. Estrogen increases renal oxytocin receptor gene expression. Endocrinology. 1995;136(4):1801-4. https://doi. org/10.1210/endo.136.4.7895693.

30. Zingg HH, Laporte SA. The oxytocin receptor. Trends Endocrinol Metab. 2003;14(5):222-7. https://doi.org/10.1016/S1043-2760(03)00080-8.

31. Gimpl G, Fahrenholz F. The oxytocin receptor system: structure, function, and regulation. Physiol Rev. 2001;81(2):629-83. https://doi.org/10.1152/ physrev.2001.81.2.629.

32. Bale TL, Pedersen CA, Dorsa DM. CNS oxytocin receptor mRNA expression and regulation by gonadal steroids. Adv Exp Med Biol. 1995;395:269-80.

33. Zhou L, Blaustein JD, De Vries GJ. Distribution of androgen receptor immunoreactivity in vasopressin- and oxytocin-immunoreactive neurons in the male rat brain. Endocrinology. 1994;134(6):2622-7. https://doi.org/10.121 0/endo.134.6.8194487.

34. Akaishi T, Sakuma Y. Estrogen excites oxytocinergic, but not vasopressinergic cells in the paraventricular nucleus of female rat hypothalamus. Brain Res. 1985;335(2):302-5. https://doi.org/10.1016/00068993(85)90481-0.

35. Shughrue PJ, Dellovade T. Merchenthaler I, Estrogen modulates oxytocin gene expression in regions of the rat supraoptic and paraventricular nuclei that contain estrogen receptor- $\beta$. Prog Brain Res. 2002;139:15-29.

36. Young LJ, Wang Z, Donaldson R, Rissman EF. Estrogen receptor $a$ is essential for induction of oxytocin receptor by estrogen. Neuroreport. 1998; 9(5):933-6. https://doi.org/10.1097/00001756-199803300-00031.

37. Chibbar R, Wong S, Miller FD, Mitchell BF. Estrogen stimulates oxytocin gene expression in human chorio-decidua. J Clin Endocrinol Metab. 1995; 80(2):567-72. https://doi.org/10.1210/jcem.80.2.7852522.

38. Acevedo-Rodriguez A, Mani SK, Handa RJ. Oxytocin and estrogen receptor $\beta$ in the brain: an overview. Front Endocrinol. 2015;6:160.

39. de Kloet R, Voorhuis DA, Boschma Y, Elands J. Estradiol modulates density of putative oxytocin receptors' in discrete rat brain regions. Neuroendocrinology. 1986;44(4):415-21. https://doi.org/10.1159/000124680.

40. Kremarik P, Freund-Mercier MJ, Stoeckel ME. Autoradiographic detection of oxytocin-and vasopressin-binding sites in various subnuclei of the bed nucleus of the stria terminalis in the rat. Effects of functional and experimental sexual steroid variations. J Neuroendocrinol. 1991;3(6):689-98. https://doi.org/10.1111/j.1365-2826.1991.tb00335.x.

41. Tribollet E, Audigier S, Dubois-Dauphin M, Dreifuss JJ. Gonadal steroids regulate oxytocin receptors but not vasopressin receptors in the brain of male and female rats. An autoradiographical study. Brain Res. 1990;511(1): 129-40. https://doi.org/10.1016/0006-8993(90)90232-Z.

42. Inoue T, Kimura T, Azuma C, Inazawa J, Takemura M, Kikuchi T, et al, Structural organization of the human oxytocin receptor gene. J Biol Chem. 1994;269(51):32451-6. https://doi.org/10.1016/S0021-9258(18)31656-9.

43. Wu S, Jia M, Ruan Y, Liu J, Guo Y, Shuang M, et al. Positive association of the oxytocin receptor gene (OXTR) with autism in the Chinese Han population. Biol Psychiatry. 2005;58(1):74-7. https://doi.org/10.1016/j. biopsych.2005.03.013.

44. Kogan A, Saslow LR, Impett EA, Oveis C, Keltner D, Saturn SR. Thin-slicing study of the oxytocin receptor (OXTR) gene and the evaluation and expression of the prosocial disposition. Proc Natl Acad Sci. 2011;108(48): 19189-92. https://doi.org/10.1073/pnas.1112658108.

45. Kushner SC, Herzhoff K, Vrshekâ€ Schallhorn S, Tackett JL. Depression in early adolescence: contributions from relational aggression and variation in the oxytocin receptor gene. Aggress Behav 2018; 44 (1): 60-68, doi: https:// doi.org/10.1002/ab.21724.

46. Bryant RA, Hung L, Dobson-Stone C, Schofield PR. The association between the oxytocin receptor gene (OXTR) and hypnotizability.

Psychoneuroendocrinology. 2013;38(10):1979-84. https://doi.org/10.1016/j. psyneuen.2013.03.002.

47. Montag C, Brockmann E, Bayerl M, Rujescu D, Müller DJ, Gallinat J. Oxytocin and oxytocin receptor gene polymorphisms and risk for schizophrenia: a case-control study. World j Biol Psychiatry. 2013;14(7):500-8. https://doi. org/10.3109/15622975.2012.677547.

48. Bird A. Perceptions of epigenetics. Nature. 2007:447(7143):396-8. https://doi. org/10.1038/nature05913. 
49. Gregory SG, Connelly JJ, Towers AJ, Johnson J, Biscocho D, Markunas CA, et al. Genomic and epigenetic evidence for oxytocin receptor deficiency in autism. BMC Med. 2009;7(1):62. https://doi.org/10.1186/1741-7015-7-62.

50. Kusui C, Kimura T, Ogita K, Nakamura H, Matsumura Y, Koyama M, et al. DNA methylation of the human oxytocin receptor gene promoter regulates tissue-specific gene suppression. Biochem Biophys Res Commun. 2001; 289(3):681-6. https://doi.org/10.1006/bbrc.2001.6024.

51. Thaler L, Brassard S, Booij L, Kahan E, McGregor K, Labbe A, et al. Methylation of the OXTR gene in women with anorexia nervosa: relationship to social behavior. Eur Eat Disord Rev. 2020;28(1):79-86. https:// doi.org/10.1002/erv.2703.

52. Kim YR, Kim J, Kim MJ, Treasure J. Differential methylation of the oxytocin receptor gene in patients with anorexia nervosa: a pilot study. Plos One. 2014;9(2):e88673. https://doi.org/10.1371/journal.pone.0088673.

53. King L, Robins S, Chen G, Yerko V, Zhou Y, Nagy C, et al. Perinatal depression and DNA methylation of oxytocin-related genes: a study of mothers and their children. Horm Behav. 2017;96:84-94. https://doi.org/10.1 016/j.yhbeh.2017.09.006.

54. Connelly JJ, Golding J, Gregory SP, Ring SM, Davis JM, Davey Smith G, et al. Personality, behavior and environmental features associated with OXTR genetic variants in British mothers. Plos one. 2014;9(3):e90465. https://doi. org/10.1371/journal.pone.0090465.

55. Micali N, Crous-Bou M, Treasure J, Lawson EA. Association Between Oxytocin Receptor Genotype, Maternal Care, and Eating Disorder Behaviours in a Community Sample of Women. Eur Eating Disord Rev. 2017;25(1):19-25. https://doi.org/10.1002/erv.2486.

56. Kim YR, Kim J, Kim C, Shin JG, Treasure J. Association between the Oxytocin Receptor Gene Polymorphism (rs53576) and Bulimia Nervosa. Eur Eat Disord Rev. 2015;23(3):171-8. https://doi.org/10.1002/erv.2354 Available from: https://onlinelibrary.wiley.com/doi/abs/10.1002/erv.2354.

57. Acevedo SF, Valencia C, Lutter M, McAdams CJ. Severity of eating disorder symptoms related to oxytocin receptor polymorphisms in anorexia nervosa. Psychiatry Res. 2015;228(3):641-8. https://doi.org/10.1016/j.psychres.2015.05.040.

58. Davis C, Patte K, Zai C, Kennedy JL. Polymorphisms of the oxytocin receptor gene and overeating: the intermediary role of endophenotypic risk factors. Nutr Diab. 2017;7(5):e279. https://doi.org/10.1038/nutd.2017.24.

59. Sala M, Han K, Acevedo S, Krawczyk DC, McAdams CJ. Oxytocin Receptor Polymorphism Decreases Midline Neural Activations to Social Stimuli in Anorexia Nervosa. Front Psychol. 2018;9:2183. https://doi.org/10.3389/fpsyg.2 018.02183

60. Kitts A, Sherry S. The single nucleotide polymorphism database (dbSNP) of nucleotide sequence variation. The NCBI Handbook. McEntyre J, Ostell J, eds. Bethesda: US National Center for Biotechnology Information. 2002

61. Buniello A, MacArthur JAL, Cerezo M, Harris LW, Hayhurst J, Malangone C, et al. The NHGRI-EBI GWAS catalog of published genome-wide association studies, targeted arrays and summary statistics 2019. Nucleic Acids Res. 2019:47(D1):D1005-12. https://doi.org/10.1093/nar/gky1120.

62. Bush NR, Allison AL, Miller AL, Deardorff J, Adler NE, Boyce WT. Socioeconomic disparities in childhood obesity risk: association with an oxytocin receptor polymorphism. JAMA Pediatr. 2017;171(1):61-7. https:// doi.org/10.1001/jamapediatrics.2016.2332.

63. Hostinar CE, Cicchetti D, Rogosch FA. Oxytocin receptor gene polymorphism, perceived social support, and psychological symptoms in maltreated adolescents. Dev Psychopathol. 2014;26(2):465-77. https://doi. org/10.1017/S0954579414000066.

64. Bradley B, Westen D, Mercer KB, Binder EB, Jovanovic T, Crain D, et al. Association between childhood maltreatment and adult emotional dysregulation in a low-income, urban, African American sample: moderation by oxytocin receptor gene. Dev Psychopathol. 2011;23(2):439-52. https:// doi.org/10.1017/S0954579411000162.

65. McQuaid RJ, McInnis OA, Stead JD, Matheson K, Anisman H. A paradoxical association of an oxytocin receptor gene polymorphism: early-life adversity and vulnerability to depression. Front Neurosci. 2013;7:128.

66. Tollenaar MS, Molendijk ML, Penninx, Brenda W. J. H, Milaneschi Y, Antypa $\mathrm{N}$. The association of childhood maltreatment with depression and anxiety is not moderated by the oxytocin receptor gene. Eur Arch Psychiatry Clin Neurosci. 2017; 267 (6): 517-526. doi: https://doi.org/10.1007/s00406-0170784-z Available from: https://www.narcis.nl/publication/RecordID/oai:pure.a tira.dk:publications\%2F63845b9f-87d5-4203-a519-d72e8e74f9e1

67. Dannlowski U, Kugel H, Grotegerd D, Redlich R, Opel N, Dohm K, et al. Disadvantage of social sensitivity: interaction of oxytocin receptor genotype and child maltreatment on brain structure. Biol Psychiatry. 2016;80(5):398405. https://doi.org/10.1016/j.biopsych.2015.12.010.

68. Goff B, Tottenham N. Early-life adversity and adolescent depression: mechanisms involving the ventral striatum. CNS Spectrums. 2015;20(4):33745. https://doi.org/10.1017/S1092852914000674.

69. Ludmer JA, Gonzalez A, Kennedy J, Masellis M, Meinz P, Atkinson L. Association between maternal childhood maltreatment and mother-infant attachment disorganization: moderation by maternal oxytocin receptor gene and cortisol secretion. Horm Behav. 2018;102:23-33. https://doi.org/1 0.1016/j.yhbeh.2018.04.006

70. Notzon S, Domschke K, Holitschke K, Ziegler C, Arolt V, Pauli P, et al. Attachment style and oxytocin receptor gene variation interact in influencing social anxiety. World J Biol Psychiatry. 2016;17(1):76-83. https:// doi.org/10.3109/15622975.2015.1091502

71. Strathearn L. Maternal neglect: oxytocin, dopamine and the neurobiology of attachment. J Neuroendocrinol. 2011;23(11):1054-65. https://doi.org/1 0.1111/j.1365-2826.2011.02228.x.

72. Ross HE, Freeman SM, Spiegel LL, Ren X, Terwilliger EF, Young LJ. Variation in oxytocin receptor density in the nucleus accumbens has differential effects on affiliative behaviors in monogamous and polygamous voles. J Neurosci. 2009;29(5):1312-8. https://doi.org/10.1523/JNEUROSCI.5039-08.2 009.

73. Tops M, Koole SL, IJzerman H, Buisman-Pijlman FT. Why social attachment and oxytocin protect against addiction and stress: insights from the dynamics between ventral and dorsal corticostriatal systems. Pharmacol Biochem Behav. 2014;119:39-48. https://doi.org/10.1016/j.pbb.2013.07.015.

74. Smarius LJ, Strieder TG, Doreleijers TA, Vrijkotte TG, Zafarmand MH, de Rooij SR. Common oxytocin polymorphisms interact with maternal verbal aggression in early infancy impacting blood pressure at age 5-6: the ABCD study. Plos One. 2019;14(6):e0216035. https://doi.org/10.1371/journal.pone. 0216035.

75. Grimm S, Pestke K, Feeser M, Aust S, Weigand A, Wang J, et al. Early life stress modulates oxytocin effects on limbic system during acute psychosocial stress. Soc Cogn Affect Neurosci. 2014;9(11):1828-35. https:// doi.org/10.1093/scan/nsu020.

76. Augustine ME, Leerkes EM, Smolen A, Calkins SD. Relations between early maternal sensitivity and toddler selfâ€ regulation: exploring variation by oxytocin and dopamine D2 receptor genes. Dev Psychobiol. 2018;60(7):789_ 804. https://doi.org/10.1002/dev.21745.

77. Rault J, Carter CS, Garner JP, Marchant-Forde JN, Richert BT, Lay DC. Repeated intranasal oxytocin administration in early life dysregulates the HPA axis and alters social behavior. Physiol Behav. 2013;112:40-8.

78. Hiraoka D, Nomura M. Maternal childhood adversity, OXTR genotype and cognitive load impact on perceptual and behavioral responses to infant crying. Psychoneuroendocrinology. 2019;104:195-202. https://doi.org/10.101 6/j.psyneuen.2019.03.005.

79. Strathearn L, lyengar U, Fonagy $\mathrm{P}$, Kim S. Maternal oxytocin response during mother-infant interaction: associations with adult temperament. Horm Behav. 2012;61(3):429-35. https://doi.org/10.1016/j.yhbeh.2012.01.014.

80. McCarthy MM. Oxytocin inhibits infanticide in female house mice (Mus domesticus). Horm Behav. 1990;24(3):365-75. https://doi.org/10.1016/0018506X(90)90015-P.

81. Riem MM, Bakermans-Kranenburg MJ, Pieper S, Tops M, Boksem MA, Vermeiren RR, et al. Oxytocin modulates amygdala, insula, and inferior frontal gyrus responses to infant crying: a randomized controlled trial. Biol Psychiatry. 2011;70(3):291-7. https://doi.org/10.1016/j.biopsych.2011.02.006.

82. Salzman JP. Ambivalent attachment in female adolescents: association with affective instability and eating disorders. Int J Eat Disord. 1997:21(3):251-9. https://doi.org/10.1002/(SICI) 1098-108X(199704)21:3<251:.AID-EAT5>3.0.CO;2-J.

83. Tasca GA, Balfour L. Attachment and eating disorders: a review of current research. Int J Eat Disord. 2014;47(7):710-7. https://doi.org/10.1002/eat.22302.

84. Monteleone AM, Cardi V, Volpe U, Fico G, Ruzzi V, Pellegrino F, et al. Attachment and motivational systems: relevance of sensitivity to punishment for eating disorder psychopathology. Psychiatry Res. 2018;260: 353-9. https://doi.org/10.1016/j.psychres.2017.12.002.

85. Ward A, Ramsay $\mathrm{R}$, Treasure J. Attachment research in eating disorders. Br J Med Psychol. 2000;73(1):35-51. https://doi.org/10.1348/000711200160282.

86. Ty M, Francis AJP. Insecure attachment and disordered eating in women: the mediating processes of social comparison and emotion dysregulation. Eat Disord. 2013;21(2):154-74. https://doi.org/10.1080/1064 0266.2013 .761089 
87. Button KS, loannidis JP, Mokrysz C, Nosek BA, Flint J, Robinson ES, et al. Power failure: why small sample size undermines the reliability of neuroscience. Nat Rev Neurosci. 2013;14(5):365-76. https://doi.org/10.1038/ nrn3475.

88. Tost H, Kolachana B, Hakimi S, Lemaitre H, Verchinski BA, Mattay VS, et al. A common allele in the oxytocin receptor gene (OXTR) impacts prosocial temperament and human hypothalamic-limbic structure and function. Proc Natl Acad Sci. 2010;107(31):13936-41. https://doi.org/10.1073/pnas.1003296107.

89. Lucht MJ, Barnow S, Sonnenfeld C, Rosenberger A, Grabe HJ, Schroeder W, et al. Associations between the oxytocin receptor gene (OXTR) and affect, loneliness and intelligence in normal subjects. Prog NeuroPsychopharmacol Biol Psychiatry. 2009;33(5):860-6. https://doi.org/10.1016/j. pnpbp.2009.04.004.

90. Chen FS, Johnson SC. An oxytocin receptor gene variant predicts attachment anxiety in females and autism-spectrum traits in males. Soc Psychol Personal Sci. 2012;3(1):93-9. https://doi.org/10.1177/194855061141 0325.

91. Malik Al, Zai CC, Abu Z, Nowrouzi B, Beitchman JH. The role of oxytocin and oxytocin receptor gene variants in childhood-onset aggression. Genes Brain Behav. 2012;11(5):545-51. https://doi.org/10.1111/j.1601-183X.2012.00776.x.

\section{Publisher's Note}

Springer Nature remains neutral with regard to jurisdictional claims in published maps and institutional affiliations.

- fast, convenient online submission

- thorough peer review by experienced researchers in your field

- rapid publication on acceptance

- support for research data, including large and complex data types

- gold Open Access which fosters wider collaboration and increased citations

- maximum visibility for your research: over $100 \mathrm{M}$ website views per year

At $\mathrm{BMC}$, research is always in progress.

Learn more biomedcentral.com/submissions 